\title{
Література:
}

1. Вайльд О. Портрет Доріана Ірея: Роман: Для ст. шк. віку / Пер. $з$ англ. та прим. Р. Доценка; К.: Школа, 2003.

2. Левицкая, Т.Р. Теория и практика перевода с английского языка на русский. М., 1963. 125 с.

3. Словник української мови URL: http://sum.in.ua/s/kucher

4. Струк І.В. Стратегії відтворення аномалій діалектного мовлення в перекладі (на матеріалі творів Марка Твена та їхніх перекладів українською та російською мовами). Гуманітарна освіта в технічних вищих навчальних закладах: зб. наук. праць. К.: Університет «Україна», 2014. Вип. 30. С. 83-97.

5. Cambridge Internetional Dictionary of English. Cambridge University Press. 2021 URL:https://dictionary.cambridge.org/dictionary/english

6. Wilde O. The picture of Dorian Gray. OriginalBook.ru, 1890.

DOI https://doi.org/10.30525/978-9934-26-073-5-2-36

\section{СПЕЦИФІКА ВІДТВОРЕННЯ ДІАЛЕКТИЗМІВ ФОНОГРАФІЧНОГО РІВНЯ ТВОРІВ ЕЛЕОНОР ПОРТЕР}

\author{
Струк I. B. \\ кандидат філологічних наук, \\ дочент кафедри англійської філології і перекладу \\ Національного авіаційного університету \\ Кривенко В. М. \\ студентка четвертого курсу \\ кафедри англійської філології і перекладу \\ Національного авіачійного університету \\ м. Київ, Україна
}

Діалекти часто відносили до неперекладного явища за рахунок розбіжностей, котрі існують у рамках різних мовних систем. I побоювання не без підставне адже, дві мови - два різних мовних континуума, живуть за різними правилами та піддаються різним процесам фонації. Звідси, коли мова іде про діалект, завдання перекладача, котре полягає у здійсненні еквівалентного відповідника стає непідйомним тягарем для перекладача, принаймні так вважалося до середини XX століття. Оскільки мовні особливості приймають вигляд ребуса відкрити ритмічну 
модель котрого можливо лише за допомогою розкодування смислових одиниць, співставлення підсистем двох мов та пошуку відповідних діалектизмів у мові перекладу, враховуючи коло читачів для яких здійснюється переклад.

Діалектизми неодноразово привертали увагу теоретиків та практиків перекладу (див. М.К. Грабовський, В.С. Виноградов, С.I. Влахов, В.Н. Комісаров, М.М. Любимов, Я.І. Рецкер, Н.В. Яковлева, Б. Девід, Е. Кліфорд, Е.К. Ландерс), проте можливість їх відтворення засобами іншої мови або взагалі заперечувалася, або визнавалася досить складним внаслідок різного роду мовних та соціокультурних обмежень. Мовні обмеження проявляються через відсутність варіативності лексичного вираження одиниць на рівні окремих систем. Соціокультурні обмеження виявляються в тому, що мовні одиниці їх вираження та контекстуальне призначення мають різні традиції в англійській та українській літературах, а отже, використання таких засобів в оригінальному та перекладеному творах не матиме аналогічного функціонального впливу [5, с. 148]. Однак, з іншого боку, правомірність такого твердження ставиться під сумнів тим беззаперечним фактом, що нейтралізація окремих діалектних одиниць може призвести до втрати важливих контекстуальних нюансів, які навряд чи можуть бути достатньо надолужені за рахунок компенсації. Усвідомлення цього простого факту змушує перекладачів шукати нові шляхи вирішення складної проблеми, переводячи іiі з мовної площини у таку, де мовні чинники взаємодіють із нормативними, психологічними та культурними. Очевидним залишається факт, що еквівалентність залежить від мети, особливостей тексту перекладу, стилю, інтенцій автора, на котрі власне має робити акцент перекладач для досягнення наближеного (еквівалентного) перекладу. Іншими словами, еквівалентність існує між двома точками: вихідний текст ↔ цільовий текст, якщо цільовий текст зорієнтований на контекст твору - зокрема його стиль, функції, то головним завданням еквівалентного відтворення першотвору залишається цілковите збереження мовних одиниць у друготворі. Безумовно, переклад діалектизмів базується не лише на контексті, однак і на його смислових та естетичних цінностях.

Матеріалом дослідження ми обрали твір Елеонор Портер «Поліанна», оскільки він рясніє цікавими для аналізу діалектами на різних рівнях мовної структури - фонетичному, лексичному, морфологічному та синтаксичному. Ці чотири рівні діалектизмів не входять в нормативну граматику, фонетику і лексику літературної мови, але іноді можуть свідомо використовуватись письменниками як стилістичний засіб для 
реалістичного змалювання життя персонажів в художніх творах [2, с. 33]. Враховуючи, обсяг роботи зупинимо нашу увагу на діалектизмах фонографічного рівня та розглянемо найбільш частотні випадки їх прояву.

1. Вилучення закінчення, яке через специфіку мовця «ковтається» при звучанні. Характерне вилучення кінцевого звука має два розгалуження, котре переважно включає у себе приголосні звуки редуковані апострофом [1, с. 53], як наприклад:»I was only keepin' on with my work...» (keeping) [7, с. 3]. - "Я лише хотіла швидше впоратися з...» [4, c. 5]. Переважно вторинні комуніканти нейтралізують або компенсують діалектизми просторіччям мови оригіналу. Щоправда зустрічаються і цікаві випадки перекладу, коли перекладачі вдаються до «створених навмисне мовних покручів із використанням елементів розмовного стилю» [3, 219], до прикладу: «...my old eyes a-seein' this» (seeing) [7, c. 10]! - «Невже мої старі очі справді побочать ї̈» [4, c. 12]?

Наступна категорія - редукція звуків на початку та всередині слова: «...'cause...» (because) [7, c. 3]. - «бo» [4, c. 5]. - «There's plenty of 'em...» [7, с. 9]. (them) [4, с. 10]. Вкотре пересвідчуємося, що переклад діалектизмів переважно здійснюється через використання літературної мови. Однак зустрічаються і цікаві шляхи перекладу, як до прикладу: "... Of course, 'twould have been a good deal harder to be glad in black» (it would) [7, с. 19]. - «Адже коли ти в чорному, набагато важче радіти» [4, с. 21]. У цьому випадку рішення перекладача виходить за рамки літературної норми (набагато - букв. значною мірою; дуже), а відтак можемо говорити про нову перекладацьку традицію, яка входить у дихотомію творчість-креативність.

Головний висновок, який можна зробити, полягає у тому, що переклад діалектизмів фонографічного рівня завжди буде нести за собою втрати 3 огляду на їх соціокультурні та культурні обмеження, які, безумовно, впливають на якість перекладу. Звідси, адекватність у перекладі досягається лише частково, завдяки використання літературної мови або просторіччя мови перекладу. При порівнянні цитат вихідного тексту вдалося виокремити цікаві випадки перекладу - використання мовних покручів, штучно створених конструкцій, мовних помилок та власне просторіччя. Перспективним $\epsilon$ комплексне дослідження відтворення граматичного та лексичного рівнів діалектного мовлення в українських перекладах творів Елеонор Портер «Полліанна» та «Полліанна виростає». 


\title{
Література:
}

1. Гудманян А.Г., Струк І.В. Відтворення фонографічних аномалій діалектного мовлення в перекладі (на матеріалі творів Марка Твена та їх перекладів українською й російською мовами). Одеський лінгвістичний вісник. Одеса. Видавничий дім «Гельветика», 2014. Вип. 4. С. 52-55

2. Кобилянський, Б.В. Діалект і літературна мова. Київ. Рад. шк. 1960. $274 \mathrm{c}$.

3. Комиссаров В. Н. Теория перевода (лингвистические аспекты). М. Высш. шк., 1990. 253 с.

4. Портер Е. Поліанна; пер. 3 англ. Богдана Гора. К. Національний книжковий проект. 2011. 240с.

5. Ребрій О.В. Сучасні концепції творчості у перекладі. Харків. ХНУ імені В. Н. Каразіна, 2012. 376 с.

6. Струк І.В. Стратегії відтворення аномалій діалектного мовлення в перекладі (на матеріалі творів Марка Твена та їхніх перекладів українською та російською мовами). Гуманітарна освіта в технічних вищих навчальних закладах. Київ. Університет «Україна», 2014. Вип. 30. С. 83-97.

7. Eleanor H. P. Pollyanna. 2018. 243 c.

DOI https://doi.org/10.30525/978-9934-26-073-5-2-37

\section{ПРОБЛЕМИ ПЕРЕКЛАДУ ДОКУМЕНТАЛЬНИХ ТРЕВЕЛ-ФІЛЬМІВ}

\author{
Шама I. М. \\ кандидат філологічних наук, \\ доиент кафедри англійської філології \\ Запорізького національного університету \\ м. Запоріжжя, Україна
}

Телевізійна тревел-продукція опинилася в сфері наукового інтересу не так давно і першими увагу на неї (що $є$ закономірним) звернули теоретики та досліджувачі журналістики [8, с. 75]. Для перекладознавців це все ще малодосліджена царина [1, с. 128; 2, с. 252]. Втім, такі фільми постійно перекладаються, будучи вагомою складовою багатьох телевізійних каналів, як от, наприклад, «Discovery», «National Geographic» або «Viasat Explorer». Практика перекладу зразків цього жанру демонструє приклади як високоякісного, адекватного транслятивного 